\title{
(JUDICIAL) MEDIATION IN ITALY AND SERBIA: COMPARATIVE LEGAL AND ECONOMIC ANALYSIS ${ }^{* *}$
}

\begin{abstract}
In this paper, the author analyzes the (judicial) mediation in Italy and Serbia from the legal and economic aspects. Given the fact that Serbia and Italy belong to the same legal system, that there are many similar problems in the regulation and implementation of mediation in practice, but also considering that Italy has gone a step further in the regulation of this legal institution primarily by introducing mandatory mediation, the aim of this paper is to provide a comparative analysis of the concepts and institutional forms of mediation in the two countries and, consequently, to observe if there are any legal solutions that Serbia could possibly adopt from the Italian legal system. We assume that the Italian experience in the regulation and implementation of mediation, and its mandatory form in particular, could serve as a solid basis for finding certain legal solutions that could potentially contribute to improving the efficiency of this legal institution in our country. The main finding is that the institutionalizing of mandatory mediation in specific disputes, primarily in disputes on civil and commercial matters, would improve the efficiency of mediation in Serbia.
\end{abstract}

Key words: efficiency, (judicial) mediation, Italy, Serbia.

\footnotetext{
*mojasevic@prafak.ni.ac.rs

** Овај рад је резултат истраживања на пројекту „Заштита људских и мањинских права у европском правном простору“, који финансира Министарство просвете и науке Републике Србије, бр. пројекта 179046.
} 


\section{Introduction}

Mediation, as a new legal institution in Serbia, is faced with many difficulties in its application. Poor regulatory framework, insufficient recognition of the importance of this legal institution by responsible individuals and general public, prejudices towards the introduction of new institutions (not only mediation) in the legal system, lack of monitoring the application of mediation in other countries, especially in those with similar legal system (etc.) are some of the factors that have contributed to compromising mediation despite its efficiency in resolving disputes (saving money and time).

On the other hand, Italy is a country that has a bit of a longer tradition in applying mediation. Besides, Italy adopted a number of legal acts on mediation in various areas of law. Yet, the application of these legal acts did not lead to a wider acceptance of mediation in Italian society, nor did it relieve the Italian courts of redundant civil cases. Reasons for such a state of affairs are quite similar to those in Serbia. However, Italy has gone a step forward by introducing a significant legal innovation - mandatory mediation. Considering that mandatory mediation generates numerous controversies in theory and practice (Quek, 2010), we want to examine the Italian experience in the application of this ADR method, with specific reference to mandatory mediation.

Italy has been selected for a comparative analysis of mediation due to the wellknown fact that Italy and Serbia belong to the European-continental legal system, that there are many similar causes of poor application of voluntary mediation in these two countries, and that the inefficiency of court proceeding is a common feature of the two judicial systems (reflected in the substantial number of backlog cases, huge caseload on the judiciary, lengthy proceedings, etc). In addition, considering that Italy is a step ahead in the regulation of this legal institution, primarily by introducing mandatory mediation in civil and commercial disputes, the goal of this paper is to compare the concepts and institutional forms of mediation in Italy and Serbia, to determine similarities and differences and, ultimately, to observe if there are any legal solutions that Serbia could possibly adopt from the Italian legal system. We assume that the experience in the regulation and implementation of mediation in Italy (and particularly its compulsory form) could serve as a solid basis for improving the efficiency of this legal institution in Serbia. In that context, the narrower concept of efficiency will be employed since the focus is on the total number of the mediation proceedings and their possible impact on the total number of civil proceedings before the national courts. Finally, the total number of mediation and civil proceedings will be established on the basis of the available official statistical data for Serbia (e.g., reports of the Supreme Court) and the available statistical data from the secondary sources for 
Italy. The qualification and evaluation of the institutional forms of mediation in Italy and Serbia, as well as the determination of the total number of solved and unsolved civil cases in two countries, will rest on the indicators from the Report of the European Commission for the Efficiency of Justice (CEPEJ), concerning the judicial systems of European countries (Jean and Jorry, 2013).

\section{Mediation in Serbia}

\subsection{Normative framework of mediation in Serbia}

The Mediation Act ${ }^{1}$ has been applied in the Republic of Serbia since 2005 as the basic legislative act on mediation as a specific ADR method. In addition, there are others relevant legislative documents regulating this matter: the Civil Contentious Procedure Act (2011), ${ }^{2}$ the Family Act (2005), ${ }^{3}$ the Act on Peaceful Resolution of Labor Disputes (2004) ${ }^{4}$ and others. In 2013, the Working group of the Ministry of Justice prepared the Draft Mediation Act, which was enacted in 2014 and entered into force at the beginning of 2015. ${ }^{5}$ Further on, we will analyze the (former) 2005 Mediation Act, primarily focusing on those provisions which depict the specific features of mediation as envisaged in Serbian law. The emphasis is on the application of the 2005 Mediation Act, since we are exploring the efficiency of mediation. It takes time to give any assessment of the effects of the new 2014 Mediation Act.

In this Act, mediation is defined as any procedure, notwithstanding its designation, in which the parties wish to settle their dispute through one or more intermediaries (mediators) who help them to reach an agreement. ${ }^{6}$ Yet, the mediator has no authority to impose a binding agreement. ${ }^{7}$ Some Serbian authors (Mihailović, 2009: 224) point out that the legislator has defined mediation as the procedure rather than as a process, primarily emphasizing the legal (procedural) aspects of mediation while neglecting other important aspects of mediation (such as psychological or economic ones).

1 Mediation Act [MA], the Official Gazette of the Republic of Serbia, 18/05

2 Civil Contentious Procedure Act [CCPA], the Official Gazette of the Republic of Serbia, $72 / 11,49 / 13$ - the decision of the Constitutional Court and 74/13 - the decision of the Constitutional Court

3 Family Act, the Official Gazette of the Republic of Serbia, 18/05 and 72/11- other act

4 Act on Peaceful Resolution of Labor Disputes, the Official Gazette of the Republic of Serbia, $125 / 04$ and $104 / 09$

5 Act on Intermediation in Resolving Disputes, the Official Gazette of the Republic of Serbia, 55/14

6 Art. 2, para. 1 of the MA

7 Art. 2, para. 2 of the MA 
The basic principles of the mediation process in Serbian law are based on the Directive of the European Parliament and of the Council of the EU on certain aspects of mediation in civil and commercial matters. ${ }^{8}$ These principles are: voluntary consent, equality of parties, privacy of the proceedings, confidentiality and urgency. When it comes to voluntary consent, it is based on the principle of disposition, which means that the mediation procedure begins with mutual consent of the two disputing parties, i.e., formally speaking, by acceptance of the proposal for mediation. ${ }^{9}$ If the party who has received the proposal for mediation fails to respond within 15 days of the receipt of the proposal, or fails to answer within the period specified in the proposal, the proposal for mediation shall be considered rejected. ${ }^{10}$ The principle of disposition is also reflected in the fact that the parties can agree on the content and course of the mediation procedure since they can determine the terms and conditions for the implementation of this procedure. ${ }^{11}$ Generally, mediation may be initiated by the parties, or the parties may be referred to mediation by the competent court, if it is deemed appropriate, but only upon the receipt of a complaint or after the preliminary hearing. ${ }^{12}$ The court may refer the parties to mediation even at a later point until the judgment becomes final. ${ }^{13}$ Mediation may also be used in the course of the appeal procedure, which features two distinct characteristics: the consent of the parties is required and the mediator can only be the judge from the official court list. ${ }^{14}$ The principle of urgency is reflected in the fact that this process must be terminated within a period of 30 days; in exceptional cases and for justifiable reasons, the period may be extended at the request of the mediator or the disputing parties. ${ }^{15}$ The principle of privacy implies that the parties, their legal representatives and proxies, as well as third parties given the parties' permission, may participate in the mediation procedure, providing that they agree to observe this principle. ${ }^{16}$ The principle of confidentiality is reflected in the provision that all information, statements and proposals related to the mediation procedure shall be confidential; exceptions are allowed only with the express and unambiguous mutual consent of the parties, or in cases where disclosure is required by the law or in the public interest, or for the purpose of enforcement

8 Directive 2008/52/EC

9 Art. 8, para. 1 of the MA

10 Art. 8, para. 2 of the MA

11 Art. 9, para. 1 of the MA

12 Art. 12, para. 1, 2 of the MA

13 Art. 12, para. 3 of the MA

14 Art. 14 of the MA

15 Art. 13 of the MA. Also, the principle of urgency is prescribed in Art. 329 of the CCPA

16 Art. 5 of the MA 
of a settlement agreement. ${ }^{17}$ Finally, the Act provided for the equality of parties, which implies that the parties shall enjoy equal rights and treatment, and that the mediator must act independently and impartially. ${ }^{18}$

In particular, the principle of voluntary consent implies that the mediation procedure is initiated and implemented upon the explicit consent of the parties, without any legal obligations. It follows that the concept of voluntary mediation is the dominant concept of mediation in Serbian law. However, as previously noted, the judge may also refer the parties to mediation, either upon the proposal of the parties or if he/she finds that the dispute could be settled successfully through mediation; in the appeal procedure, the parties may be referred to mediation only upon obtaining their express consent. Yet, the mediation procedure rules envisaged in the Mediation Act may also apply to the mediation procedure which has been initiated without the instruction of the court or other authority, either before or after the initiation of the judicial proceeding. ${ }^{19}$ This legal norm implies that the mediation procedure rules may also apply to private mediation proceedings.

Finally, the Mediation Act stipulates that the agreement reached in the mediation proceeding has the power of an out-of-court settlement, provided that it is made in writing and that is not contrary to the public policy. ${ }^{20}$ In order to make the agreement enforceable, the parties must take some additional legal actions; specifically, they are required to initiate a special non-contentious proceeding and submit additional costs (the cost of the proceeding, lawyer fees and the waste of time from the moment of concluding the agreement until the moment when it becomes enforceable).

17 Art. 6, para. 1 of the MA

18 Art. 4 of the MA

19 Art. 1, para. 2 of the MA

20 Art. 16, para. 4 of the MA 


\subsection{Mediation and Litigation in Serbia: some quantitative macro indicators}

Let us examine the data provided in the following graph: ${ }^{21}$

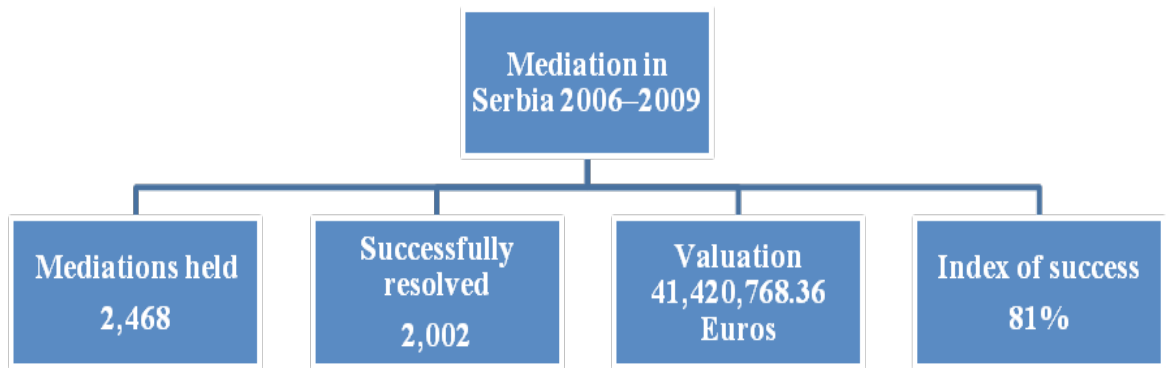

Graph 1. Data on the total number of mediations in Serbia (2006-2009), http://www.medijacija. rs/img/rezultati2009.pdf

In the period from 2006 (when the Mediation Act entered into force) to 2009, Serbia had a total of 2,468 mediations, 2,002 of which were successfully completed (by signing the agreement). The total value in these mediations amounted to $41,420,768.36$ Euros. The index of success is quite high and amounts to $81 \%$. Moreover, in the entire period from 2006 until October 2013, there were slightly more than 3,500 cases settled by means of mediation. ${ }^{22}$

On the other hand, according to the Report of the Supreme Court of Serbia for the year $2012,{ }^{23}$ the total number of unresolved cases, which are transferred from previous years to be adjudicated by the courts of general jurisdiction, amounts to $\mathbf{2 , 7 4 5 , 5 6 9}$; the total number of new cases amounts to $\mathbf{1 , 2 1 9 , 4 9 0}$ whereas the total number of cases resolved by the end of 2012 amounts to $\mathbf{1 , 3 4 3 , 5 6 7 .}$ At the end of 2012, there were a total number of $\mathbf{2 , 6 2 1 , 3 0 3}$ cases pending. If we compare the data on the total number of pending cases for the year 2012 with the same data for the year $2011(2,742,772),{ }^{24}$ it is evident that the situation in terms of the total number of pending cases has not changed substantially as

21 For the purposes of this empirical study (Mojašević, 2014), the data were taken from the website of the Mediation Center of the Republic of Serbia, based in Belgrade. Meanwhile, as the work of a new legislative act has been underway, the Centre has stopped working because the new Mediation Act does not envisage such a center.

22 Information taken from: http://novosti.rs/vesti/naslovna/drustvo/aktuelno.290. html:460347-Gasi-se-Centar-za-medijaciju, access: 10 September 2014.

23 Report of the Supreme Court of Serbia for year 2012 available at: http://www.vk.sud. rs/assets/files/o_sudu/izvestaji/statistika_2012.pdf

24 Report of the Supreme Court of Serbia for year 2011 available at: http://www.vk.sud. rs/assets/files/aktuelno/statistika_o_radu_sudova_za_2011.pdf 
there were more than two and a half million cases pending before Serbian courts of general jurisdiction in late 2011 and 2012. According to the Report of the Supreme Court of Serbia in $2010,{ }^{25}$ the total number of pending cases before the courts of general jurisdiction at the end of the reporting period amounted to $\mathbf{9 7 9 , 9 6 9}$. This data indicates a huge increase in the number of cases pending in the period from 2010 to 2012. Moreover, from the total number of pending cases in 2011 and 2012 , about $97 \%$ of them were cases before the primary courts, which clearly shows that the Serbian primary courts bear the largest caseload.

The Report of the Supreme Court of Serbia for year 2012 also indicates that almost every second case brought before the primary courts in 2012 was actually an overdue (old) case (about 44\%) while this percentage was somewhat lower in 2011 (about 33\%). ${ }^{26}$ It is obvious that the number of backlog cases before the primary courts increased from 2011 to 2012, and that the backlog of old cases is quite high (almost every second, or nearly one-third of cases in the observed year) in relation to the total number of cases before the primary courts. The largest backlog of cases before the primary courts are those pending for resolution from 5 to 10 years $(538,524)$, followed by cases pending for 3 to 5 years $(469,064)$, then cases pending for 2 to 3 years $(442,672)$, and case pending for over 10 years $(190,663)$. In 2011, the situation is identical in terms of the time limit for resolving old cases before the Serbian first-instance courts. We see that about $33 \%$ of the total backlog of old cases are cases pending for resolution from 5 to 10 years. If we add to this percentage about $28 \%$ of the cases pending for resolution from 3 to 5 years, it follows that over $50 \%$ of cases (every second case) are pending for resolution from 3 to 10 years before the Serbian primary courts. An interesting fact is that the cases pending for resolution from one to two years constitute about $0.5 \%$ of the total backlog of old cases. Therefore, the Serbian primary courts certainly cannot be pleased about the time dimension for resolving cases.

Another interesting piece of data concerns the average backlog of cases per judge for the year 2012: 56.62 cases in the Serbian Supreme Court of Cassation; 95.36 cases in Appellate Courts; 69.78 cases in Superior Courts; 1,501.44 cases in primary courts. On the other hand, the average number of backlog cases per judge in Serbian primary courts for the year 2011 amounted to 1,348.65. We see that the load of old cases per judge increased from 2011 to 2012, which is quite high at least when it comes to primary courts.

25 Report of the Supreme Court of Serbia for year 2010 available at: http://www.vk.sud.rs/assets/files/o_sudu/izvestaji/godisnji_izvestaj_o_radu_2010.pdf 26 It is the old cases by date of the initial act. 
All in all, the total number of old cases pending for resolution before the Serbian courts of general jurisdiction increased from 2010 to 2012 year; the percentage of old cases pending before the courts of general jurisdiction (including primary courts) increased from 2011 to 2012 and, in general, that percentage is quite high. The load of cases per judge is high, whereby the Serbian primary courts bear the largest caseload. Moreover, most parties (over half a million) wait for the resolution of disputes between 5 and 10 years. This last statement is particularly revealing if it is interpreted in the following way: given the fact that each procedure involves at least two parties, it follows that about a million Serbian citizens wait for justice more than five years. In addition, including the number of those citizens who wait for an end to the dispute between 3 and 5 years (almost half a million), it turns out that over two million people in Serbia wait for the resolution of dispute for more than three years!

Considering that the mediation departments were mainly founded within the Serbian primary courts, it was expected that these courts would be relieved of redundant cases, primarily the backlog from previous years. Thus, other courts of general jurisdiction would also be relieved of redundant caseload. However, these expectations have not been met; moreover, they have been fully betrayed! Comparing the total number of 3,500 cases resolved in mediation (from 2006 to 2013) to a total of 2.5 million cases pending for resolution (in 2011 and 2012) and nearly 1,700,000 backlog of old cases by date of initial act (in 2012) pending in the courts of general jurisdiction, ${ }^{27}$ it is evident that the introduction of mediation into the legal system of the Republic of Serbia has not contributed to relieving the courts of excessive caseload. Moreover, the data on individual workload of judges and the time required for completion of the judicial procedure lead to the same conclusion.

\subsubsection{Mediation and Litigation in Serbia: micro aspect}

The efficiency of mediation and litigation was the subject matter of empirical research conducted in late 2011 and the beginning of 2012 in the Primary Court in Niš (Mojašević, 2014). Given the fact that Niš is the third largest city in Serbia, the cases that were subjected to litigation and mediation at the Primary Court in Niš served as a solid foundation for testing the effects of application of the Mediation Act in Serbia, as well as for the purpose of gaining some knowledge on the efficiency of mediation. The findings of this study indicate that mediation has not lived up to general expectations, i.e. that the efficiency of this legal institution has not been put to full effect in practice.

27 The backlog of old cases in 2011 amounted to nearly one and half million $(1,452,793)$. 
This empirical research has identified the possible reasons for insufficient use of mediation in Serbia. These main reasons are: a) inadequate legal solutions, primarily the current concept of voluntary mediation and court-ordered mediation which was rather ineffective, as well as the fact that the agreement reached in the mediation proceeding has the power of an out-of-court settlement; b) high costs for initiating a mediation proceeding which discourage the parties to resort to mediation, particularly in small claims cases; c) lack of relevant information on the mediation process to parties and other participants in the mediation procedure; d) insufficient popularization of mediation in Serbia; e) insufficient educational activities on the benefits of mediation; etc. (Mojašević, 2014: 236-245).

\section{Mediation in Italy}

\subsection{Mandatory mediation in civil and commercial disputes in Italy}

ADR methods, and particularly mediation, have been known in Italy for a long time but they received closer attention at the end of the $20^{\text {th }}$ century. Concurrently, the legislator intensified the activity in the field of regulating mediation. But, the most significant change in terms of regulating mediation in Italy took place in 2009 when the Italian Parliament adopted the Law No. 69/2009. Under this act, the Government was authorized to regulate mediation in civil and commercial matters. Thus, the Government passed a special decree (the Legislative Decree 28/2010), which introduced the concept of mandatory mediation prior to initiating court proceedings in civil and commercial matters. Further on, we will focus on the concept of mandatory mediation and its implications for the efficiency of judicial proceedings in Italy.

The Legislative Decree $28 / 2010^{28}$ prescribes, in specified disputes, ${ }^{29}$ the parties' obligation to participate in mediation as a condition for initiating a court proceeding. This is a mandatory attempt to settle the dispute before the mediator rather than an obligation to accept any agreement. In the event that the parties fail to comply with this obligation and directly turn to litigation, the court is required to suspend the case and order the parties to participate in mediation. Similarly, in case of parties' non-compliance with these obligations in the circumstances

28 The most important provisions of this Decree can be found at:

http://www.adrcenter.com/procedure/international-procedures/mediation-italian-law/

29 Mandatory mediation is envisaged in the following disputes: co-ownership of land, property rights, division of assets, trusts and estates, family agreements, leasing, loans, commercial leases, medical malpractice, defamation, car and boat accidents, insurance, and banking and financial agreements. 
where mediation has been stipulated in the contract (in the form of contractual clauses) or in relevant internal company acts, the judge (or arbitrator) may issue an order to initiate mediation within a period of 15 days; concurrently, the judge (arbitrator) is required to postpone the court proceeding until the termination of the mediation process. Once the mediation procedure has been initiated, the Decree prescribes that in case of a party's default (unjustified failure to appear and/or participate in the mediation process) the judge may take this fact into account at a later point in the civil proceeding, which may have a negative effect in the process of presenting the evidence. ${ }^{30}$ Specifically, the refusal to participate in mediation may be regarded as a refusal to file certain documents in court proceeding. On the one hand, this provision is reinforced by special decree (D.L. 138/2011), which prescribes payment of a sum of money to the state as a penalty (fine) for unreasonable failure to participate in the mediation process; on the other hand, the provision of this special decree is repealed by another decree - L. 03/24/2012, n. 27 (Colombo, 2012: 77).

There are a lot of important and interesting solutions introduced by this Decree. Here, we single out the most representative ones (Gabellini, 2010: 65-66). First of all, the lawyers are obliged to inform their clients in writing about the possibility of settling the dispute by means of mediation. Second, the mediation process may not exceed a period of four months from the date of submitting the request for mediation to an accredited mediation center. Third, in mediation, documents or actions are not subject to the payment of any taxes and charges, and the agreements contracted in cases not exceeding the value of 50,000 Euros are exempt from registration costs. In case the parties conclude a mediation agreement, they may receive a tax credit in the amount of 500 Euros, or 250 Euros in case of a negative outcome. Fourth, all mediation centers have to be accredited by the Ministry of Justice, which keeps a unique Register of mediators, and mediators must undergo a special training prescribed by the respective ministry. Fifth, the mediator is empowered to make a proposal to facilitate the conclusion of agreements; the party who rejects the proposal is required to pay all the costs of the civil proceeding (even if he/she wins the case) if the court decision is identical to the proposal. Moreover, if the judgment is not identical to the mediator's proposal, the judge may order the party who won the case to pay its own costs, provided that there are legitimate reasons (for example, gross negligence by the party in rejecting the mediator's proposal). This provision is envisaged as a preventive measure for resolving disputes through mediation. Yet, the Italian theory (Colombo, 2012: 77) states that this provision is quite controversial, taking into account the well-known fact that the mediation agreement need not necessarily be based on matters of law; on the other hand, this

30 Art. 8 of the Decree. 
preventive measure (the threat of the allocation of costs) can be effective only if the proposed agreement is identical to the judgment (which is, by definition, based on matters of law). Besides, the threat of allocation of costs is aimed only at the plaintiff. Finally, the mediation agreement becomes enforceable in a simple procedure, only upon being officially confirmed by the competent court (Tribunal), where the agreement is subjected to formal control to ensure that it is consistent with the public policy and the mandatory legislation. In addition, the Tribunal verifies whether the rules of mediation procedure have been fully observed. ${ }^{31}$

This Decree was applied until the end of 2012, when the judges of the Constitutional Court of Italy made a decision (Award No. 272/2012) that it was not in accordance with the Constitution of Italy. The objection of the Constitutional Court was focused on the procedural issue concerning the delegation of powers in the adoption of the act on the implementation of mandatory mediation rather than on the question of violation of the rights to defense which was allegedly violated by introducing mandatory mediation (as claimed by the Bar Association of Italy). ${ }^{32}$ The Constitutional Court did not venture into the assessment of whether the introduction of mandatory mediation in the national legal system was in accordance with the Directive 2008/52/EC but only reasoned that there was a breach of the delegation of powers and that the mandatory mediation must have its legal grounds in the national legislation. After the Constitutional Court rendered such a decision, the Decree of 2010 was significantly modified. It was done by adopting a new decree (Legislative Decree No. 69/2013) on "Urgent Measures on economy stimulation". This time, mandatory mediation will be applied in four (experimental) years, after which the competent ministry will be obliged to evaluate the results of mediation. The most relevant modifications are: ${ }^{33}$ a) the number of prescribed disputes in which parties are obliged to pursue mediation was reduced (for example, the parties are no longer obliged to pursue mediation in case of damages arising from car and boat accidents); b) the parties are given the opportunity to opt out of mediation in the initial phase of the process if they estimate that it will not result in a mediation agreement, whereby the party who refuses the (non-binding) agreement proposed by the mediator will be obliged to pay all the costs if the judgment is identical to the mediator's proposal; ${ }^{34}$ and c) the Decree prescribes the obligatory participation

\section{Art. 12 of the Decree}

32 The curiosity is that the Italy's National Lawyers Union organized a five-day national strike against the Decree 28/2010.

33 http://kluwermediationblog.com/2013/10/09/mandatory-mediation-in-italy-reloaded/

34 This controversial provision, which was also included in the Decree of 2010 , has become the subject matter of a heated debate. Given the fact that mediation is traditionally seen as 
of lawyers in the mediation process, which is evidence that the lawyer's lobby has succeeded in protecting their interests.

\subsection{Some statistical data on the (mandatory) mediation in Italy}

Statistically, Italy cannot be proud of the results of the voluntary mediation in terms of the number of initiated mediation procedures. The data (Gabellini, 2010: 64 ) suggests that the first major reform in the area of corporate law (when the voluntary mediation was introduced) did not give significant results: slightly more than 150 cases were presented to mediation; if we add the cases outside the area of corporate law, the outcome is about 3,000 cases; less than $0.1 \%$ of cases pending in court were voluntarily presented to mediation, while the index of success of those cases which were mediated was high (80\%). The following data also support a small number of mediation in Italy: ${ }^{35}$ from 1999 to 2005, The ADR Center in Rome, the largest accredited center for mediation in Italy, launched 327 mediation proceedings, 277 of which were initiated by one party to the dispute, 45 proceedings were intended as a contractual obligation, 3 mandatory mediation proceedings pertained to the telecommunications sector and 2 proceedings were instigated upon the judge's proposal.

Such statistics have forced the Italian legislator to re-examine the concept of voluntary mediation. The Italian legislator embarked on two tracks of action (Gabellini, 2010: 64-65): the first course of action was aimed at introducing the legislative reform, which resulted in gradual introduction of mandatory mediation in certain disputes; the second course of action was aimed at improving the quality of mediation services, by introducing accreditation for mediators and special training programs.

According to publicly available data, ${ }^{36}$ in the period from March 2011 (when mandatory mediation started being implemented) until October 2012, 215,689 mediation proceedings were initiated, with an average success rate of $12 \%$. The defendants were not obliged to participate in these proceedings. Therefore, taking into account the proceedings where the defendants voluntarily agreed to participate, the success rate is much higher and amounts to around $50 \%$. Also, in the period from March 2011 to March 2012, less than 3\% of mediation cases were initiated at the suggestion of the judge, which is a slight increase as compared to the first nine months of this period, when the increase was $2 \%$. De

a facilitative institution, there is a question whether this provision may significantly affect the traditional concept of mediation, which may thus acquire some feature of evaluative institution.

35 http://www.europarl.europa.eu/comparl/juri/hearings/20071004/depalo5_en.pdf

36 http://kluwermediationblog.com/2013/10/09/mandatory-mediation-in-italy-reloaded/ 
Berti (2012) points out that this slight increase in percentage may reflect the change in otherwise very reserved attitude of the Italian judges to mediation. Then, when it comes to the controversial provisions of the Decree on the authorization of the mediator to draft a proposal agreement, the statistics indicate that mediators took initiative in this direction in only $1 \%$ of the initiated mediation proceedings; on the other hand, the parties requested that the mediator prepare a proposal agreement in $0.5 \%$ of all cases (Colombo, 2012: 79). Finally, the introduction of mandatory mediation resulted in a drastic increase in the number of centers for providing mediation services and the number of institutions which provided instruction on mediation. In 2008, there were 37 mediation centers in Italy but by the end of April 2012 this number increased to 843 (which means that the number of centers increased 23 times); concurrently, the number of institutions dealing with education in this area increased from 35 to 309 over the same time period (De Berti, 2012). In Italian theory (Colombo, 2012: 78), it gave rise to another question: was this increase in the number of centers and educational institutions really necessary, and how would it affect the quality of provided mediation services?

\section{An attempt at qualifying the concepts of mediation in Italy and Serbia}

Prima facie, we may identify some similarities and differences underlying the concepts of mediation in Italy and in Serbia. First of all, the dominant concept in Serbia is the concept of voluntary mediation, which is either initiated by the parties or upon the referral of a judge. As far as the latter is concerned, in Serbian theory (Knežević and Pavić, 2009: 240) there is the interpretation that this concept implies a mandatory court mediation because in the first instance judicial procedure (unlike the procedure on appeal) ${ }^{37}$ the parties are obliged to pursue mediation they have been referred to by the trial court judge. However, the interview with the Coordinator of the Department of the Mediation Centre in Niš showed that the judges generally took into consideration the will of the parties in the process of referring them to mediation; "a judge refers the parties to mediation only if the parties agree to mediate" (Mojašević, 2014: 216). There is an obvious discrepancy between the theoretical interpretation of this important provision of the Mediation Act, which reflects the essence of the concept of mediation, and the judicial interpretation and actual application of this provision in judicial practice (at least when it comes to the Primary Court in Niš). In Serbia, mediation proceedings are usually carried out in specific departments which are organizationally and spatially connected with the first-instance courts; such a

37 In the appeal procedure, the consent of parties to go to mediation is required. See: Art. 14 of the MA 
proceeding is designated as court-annexed mediation..$^{38}$ On the other hand, there are several types of mediation in Italy: voluntary mediation, mandatory mediation and mediation upon the referral of the trial judge. The feature that makes the Italian and the Serbian legal frameworks significantly different is primarily embodied in the institution of mandatory mediation in specific types of disputes.

According to the CEPEJ Report issued in 2012 and based on the data from 2010 (CEPEJ, 2012: 132-141), Serbia is one of the 26 European countries which have a court annexed mediation (mediation instituted upon the referral of the trial judge); on the other hand, Italy falls into the largest group of European countries (a total of 31, including Serbia) where private mediation is the most dominant form of mediation. In terms of civil and commercial disputes, Serbia falls into the group of 22 European countries predominantly using court-annexed mediation, while Italy falls into the group of 26 European countries (including Serbia) predominantly using private mediation. Both countries fall into the group of 13 countries where the judge may act as a mediator in the case at issue. The situation is similar in family matters and labor law matters (termination of employment). The distinctive feature of mediation in Italy is that it is not envisaged for resolving administrative disputes, which is the case in Serbia. In Italy, mediation is generally not applied in criminal matters, except in specific cases (such as, juvenile delinquency). Generally speaking, in terms of the forms of mediation, it can be concluded that the only difference between Italy and Serbia is that in Italy there is no court-annexed mediation ${ }^{39}$ and mediation at the prosecutor's proposal_in criminal matters. In addition, in Serbia, mediation has a wider scope of application in terms of different types of legal disputes.

When comparing the mediation in civil and commercial matters in Italy and Serbia, we may observe one major difference: in Italy, mediation proceedings are generally conducted before the chambers of commerce, which do not have such an important role in Serbia. In Serbia, mediation proceedings in civil and commercial matters are generally carried out under the auspices of the courts, as the court-annexed mediation. It is worth mentioning that there have been attempts in Serbia to institutionalize mediation within the chambers of

38 Mediation is possible out of the courts, within special authority or organization. For example, under the auspices of a special state body the Commissioner for Protection of Equality mediation is possible in discrimination cases.

39 However, the outset of the legislative reform in Italy was aimed at the institutionalization of court-annexed mediation (by introducing the special judicial office in 1991) but, later on, the reform took a different turn and resulted in establishing mediation centers outside the courts, particularly within the chambers of commerce. 
commerce, for which reason the legislator passed a special legislative act; ${ }^{40}$ unfortunately, these attempts have not given significant results. According to the data from 2012 (Ljubović, 2012: 56), only 16 claims were submitted to the Serbian Chamber of Commerce to initiate proceedings on the consensual financial restructuring of corporate debts by redefining the debtor-creditor relationship between the company in financial crisis and its creditors. In most cases, the claims were submitted by debtors who had been facing substantial financial hardship.

The following two tables summarize the similarities and differences in the concepts of mediation as well as in the institutional forms of mediation in Italy and Serbia:

\begin{tabular}{|ccc|}
\hline Concepts of mediation & Italy & Serbia \\
\hline Voluntary mediation & Yes & Yes \\
\hline $\begin{array}{c}\text { Mandatory mediation } \\
\text { Mediation by } \\
\text { judicial referral }\end{array}$ & Yes & No \\
\hline
\end{tabular}

Table 1. Concepts of mediation: comparison

\begin{tabular}{|ccc|}
\hline $\begin{array}{c}\text { Institutional forms } \\
\begin{array}{c}\text { Court-annexed } \\
\text { mediation }\end{array}\end{array}$ & Italy & Serbia \\
\hline Private mediation & Most dominant form & $\begin{array}{c}\text { Secondary } \\
\text { importance }\end{array}$ \\
\hline Judge as a mediator & Yes & Yes \\
\hline $\begin{array}{c}\text { Mediation within } \\
\text { chambers of commerce }\end{array}$ & Yes & $\begin{array}{c}\text { At the initial stage } \\
\text { of development }\end{array}$ \\
\hline
\end{tabular}

Table 2. Institutional forms of mediation

40 Act on Consensual Financial Restructuring of Companies, the Official Gazette of the Republic of Serbia, 36/11 


\section{What can Serbia learn from the Italian experience?}

The common feature of the judicial systems in both countries is the inefficiency of court proceedings, which is reflected in the substantial number of backlog cases, huge caseload on the judiciary, lengthy proceedings, etc. On the other hand, the differences between the two countries are reflected in the response to these pressing problems in the judicature. Despite the imminent risk, Italy has demonstrated determination to deal with these problems, primarily by introducing the mandatory mediation in specific cases. On the other hand, Serbia seems to be at the beginning of this process. In fact, after almost ten years of applying the Mediation Act, Serbia had enough time to clearly examine the causes of insufficiency of (voluntary) mediation in practice and take relevant measures to improve the efficiency of this legal institution. Instead, Serbian legal scholars and professionals have been unnecessarily involved in extensive and exhausting (ideological) debates on the concepts of mediation; the ultimate result was the adoption of the new Draft Mediation Act at the end of 2013, and subsequently the new 2014 Mediation Act which offers some new solutions ${ }^{41}$ but, on the whole, does not appear to be too promising (Mojašević, 2014). The only logical course of action should have been a more pragmatic approach to these problems. The experiences of other countries (including Italy) could have served this purpose. Italy is suitable for a comparative study not only because the Italian mediation framework inter alia includes similar causes of insufficient use of (voluntary) mediation but also because it provides different instruments to overcome this problem, the most significant of which is mandatory mediation. In this regard, it has been theoretically confirmed (Quek, 2010) that mandatory mediation may contribute to raising awareness about the importance of mediation as a legal institution and its popularization. Although the final conclusions may be too early to draw, the Italian experience with mandatory mediation bears evidence of the initial good results in its implementation.

The concept of voluntary mediation is certainly the most adequate form of mediation; but, what happens in case it does not yield the expected results? Italy has given some kind of answer but Serbia, unfortunately, has not even started addressing the problem. When considering the introduction of a new legal institution, such as mediation, the legislator should take into account the

41 We draw attention to two new solutions which, in our opinion, can contribute to the efficiency of mediation. First, the mediation agreement may have the power of an enforcement order if the subject of the agreement is the performance of the obligation, if it includes a statement by which the debtor accepts the agreement as enforceable, and if the signatures of the parties and the mediator on the agreement are certified by the court or a notary public. Second, the parties are exempted from paying court or administrative fees in the event the agreement is signed after the initiation of judicial or other proceeding but prior to the termination of the first trial hearing. 
characteristics of the culture of a specific country. Obviously, the Serbian legislator has failed to do so because Serbia has uncritically accepted the concept of voluntary mediation, having high expectations that this concept will contribute to improving the efficiency of judicial proceedings. Considering the fact that it did not happen (as it could have been assumed) ${ }^{42}$ and given the precious time which has been wasted in the past ten years, we should better learn some practical lessons from the experience. Both the Serbian and the Italian experience speak in favor of introducing mandatory mediation, as a temporary practicable solution, which is primarily aimed at reducing the backlog of cases burdening the judicial system in Serbia and, consequently, increasing the costs of business operations.

To sum up, the specific measures taken in Italy for the purpose of improving the efficiency of court proceeding may also be introduced in Serbia; they are reflected in institutionalizing of mandatory mediation in specific disputes, primarily in disputes on civil and commercial matters. It should contribute to the popularization of this legal institution in Serbia and increase the frequency of mediation proceedings. The Serbian mediation system may also be improved by introducing a simple procedure for the enforcement of the mediation agreement, which is envisaged and implemented in Italian law. Many other solutions envisaged in the Italian law may contribute to increasing the frequency of mediation, such as the solution on exempting the parties from paying various taxes. Moreover, the Italian experience of using mediation within the chambers of commerce across Italy can certainly help in promoting mediation proceedings within the Serbian chambers of commerce. To that effect, the chambers of commerce of the two countries need to establish closer cooperation. From the Italian experience we may also learn about the unnecessary heterogeneous and complex legislative process on this matter, which is reflected in the implementation of a partial legislative reform. Serbia managed to avoid that (to some extent) by adopting the 2005 Mediation Act as the basic legislative act on this matter and by institutionalizing the court-annexed mediation for a vast range of legal disputes. However, little has been done in the area of applying the laws, primarily at the institutional and organizational level, in the field of promoting mediation and providing for the education of the disputing parties and other participants in the mediation proceeding about the importance of this legal institute. This confirms the thesis that a legislative reform (although necessary) is insufficient for the recognition and affirmation of any legal institute, including mediation.

42 The concept of voluntary mediation may be more appropriate and successful in countries where the awareness of the peaceful dispute settlement is high and where dispute resolution in courts is expensive (like the U.S.). In contrast, in a country such as Serbia, where the institute of mediation is insufficiently acknowledged and where it is relatively easy to initiate a court proceeding, it could have been expected that this legal institute would not provide significant results in terms of improving the efficiency of court proceedings.

* Proofreading: Gordana Ignjatović 


\section{References}

Colombo, G. F. (2012). Alternative Dispute Resolution (ADR) in Italy: European Inspiration and National Problems. Ritsumeikan Law Review. 29. 71-80.

De Berti, G. (2012). Mandatory mediation: the Italian experience, two years on. [Electronic version]. Retrieved 10.12.2014.

http://www.internationallawoffice.com

Gabellini, R. (2010). The Italian Mediation Law Reform. ADR Bulletin. 12. 1-7. [Electronic version]. Retrieved 1.12.2014.

http://epublications.bond.edu.au/adr/vol12/iss3/4

Knežević, G. Pavić. V. (2009). Arbitraža i ADR. Beograd: Izdavački centar Pravnog fakulteta Univerziteta u Beogradu.

Ljubović, N. (2012). Medijacija u privredi. In Nedić, B. and Toskić, A. (Ed.). Primena medijacije u Srbiji: dostignuća i izazovi. Beograd: Partneri za demokratske promene.

Mojašević, A. (2014). Ekonomska analiza medijacije: teorijsko-empirijska studija. Niš: Centar za publikacije Pravnog fakulteta u Nišu.

Quek, D. (2010). Mandatory Mediation: An Oxymoron? Examining the Feasibility of Implementing a Court-Mandated Mediation Program. Cardozo Journal of Conflict Resolution. 11. 479-509.

Mihailović, G. (2009). Šta smo dobili a šta izgubili sa zakonom o medijaciji. In Ignjatović, T. Dž. and Žegarac, N. (Ed.). Teorijske osnove medijacije: perspektive $i$ doprinosi. Beograd: Centar za primenjenu psihologiju.

\section{Legal sources:}

Act on Consensual Financial Restructuring of Companies. The Official Gazette of the Republic of Serbia. No. 36. 2011.

Act on Intermediation in Resolving Disputes. The Official Gazette of the Republic of Serbia. No. 55. 2014.

Act on Peaceful Resolution of Labor Disputes. The Official Gazette of the Republic of Serbia. No. 125. 2004. and 104. 2009.

Civil Contentious Procedure Act [CCPA]. The Official Gazette of the Republic of Serbia. No. 72. 2011, No. 49. 2013. - the decision of the Constitutional Court and No. 74. 2013. - the decision of the Constitutional Court. 
Directive of the European Parliament and of the Council of the EU on certain aspects of mediation in civil and commercial matters (Directive 2008/52/EC). Family Act. The Official Gazette of the Republic of Serbia. No. 18. 2005. and 72. 2011.

Mediation Act [MA]. The Official Gazette of the Republic of Serbia. No. 18. 2005. Reports:

European Commission for the Efficiency of Justice (CEPEJ), Council of Europe (2012). European judicial systems, Edition 2012 (data 2010): Efficiency and quality of justice.

Jean, J. Jorry. H. (2013). Judicial systems of the European Union countries, Analysis of data by the European Commission for the Efficiency of Justice (CEPEJ). Council of Europe.

Report of the Supreme Court of Serbia for the year 2012, available at: http:// www.vk.sud.rs/assets/files/o_sudu/izvestaji/statistika_2012.pdf

Report of the Supreme Court of Serbia for the year 2011, available at: http:// www.vk.sud.rs/assets/files/aktuelno/statistika_o_radu_sudova_za_2011.pdf

Report of the Supreme Court of Serbia for year 2010 available at:

http://www.vk.sud.rs/assets/files/o_sudu/izvestaji/godisnji_izvestaj_o_ radu_2010.pdf

Internet sources:

http://kluwermediationblog.com/2013/10/09/mandatory-mediation-in-italyreloaded/

http://novosti.rs/vesti/naslovna/drustvo/aktuelno.290.html:460347-Gasi-seCentar-za-medijaciju

http://www.adrcenter.com/procedure/international-procedures/mediationitalian-law/

http://www.europarl.europa.eu/comparl/juri/hearings/20071004/depalo5_ en.pdf

http://www.medijacija.rs/img/rezultati2009.pdf 


\title{
Др Александар Мојашевић,
}

Доцент Правног факултета, Универзитет у Нишу

\section{(СУДСКА) МЕДИЈАЦИЈА У ИТАЛИЈИ И СРБИЈИ - КОМПАРАТИВНА ПРАВНО-ЕКОНОМСКА АНАЛИЗА}

\begin{abstract}
Резиме
Предмет анализе у овом раду јесте (судска) медијација у Италији и Србији, са правног и економског аспекта. Полазећи од тога да Италија и Србија припадају истом правном систему, да постоје бројни слични проблеми у регулисању и примени медијације у пракси, као и од чињенице да је Италија отишла корак напред у регулисању ове правне установе, пре свега увођењем обавезне медијације, циљ овог рада је компаративно проучити концепте и институционалне форме медијације у две земље и, консеквентно, установити да ли постоје одређена правна решења која би Србија могла да усвоји из италијанског правног система. Полазимо од тога да италијанско искуство у регулисању и примени медијације, посебно њене обавезне форме, представља солидну основу за проналажење одређених правних решења која би евентуално могла да допринесу побољшању ефикасности ове правне установе у нашој земљи. Главни налаз јесте да би увођење обавезне медијације у одређеним споровима, пре свега у грађанским и трговинским споровима, побољшало ефикасност медијације у Србији.
\end{abstract}

Кључне речи: ефикасност, (судска) медијација, Италија, Србија. 